\title{
Recovering the mundane practices of economic time
}

\section{Jacqueline Best}

University of Ottawa, Canada

Martijn Konings has given us an elegant, erudite book that points to the centrality of speculation - and a speculative logic of time - in modern political economy. At the heart of Konings' thesis is a stark refusal to accept the ontological dichotomy between real and fictitious economies that drives so much critical and heterodox economic scholarship. Speculation, he argues, does not represent a rupture from the 'real' world of value and production that faces a comeuppance in moments of crisis as its fictions are forced to confront reality. Instead, speculation is the driving force behind modern finance and its central feature, money, both of which operate through a pre-emptive temporal logic: money's value is always dependent on securing an uncertain future.

Konings develops this conception of capital's temporality through a particularly powerful concept - that of leverage. If the value of a given financial institution's credit depends on its actualization in an unknown future, then it also depends on others' accepting it as valuable. If that bank can convince enough others of its credit's value - and can integrate them into its network - then it will help to secure its future value. The kind of leverage that is at the heart of this process of producing monetary value is therefore not only contingent and speculative, but is also immensely social and political. It is not just institutions but people, objects, and expectations that must all be drawn together if the neoliberal bet is to succeed.

It is this concept of leverage, I will argue here, that is Koning's most important contribution to an immanent theory of the logic of neoliberal finance. However, the true potential of this concept - and its capacity to overcome the dualism of the ideal and material - has yet to be fully realized in this book. Although Konings takes great care to tell a nuanced story, grounding his bigger theoretical claims in the more mundane stuff of history, the book at times feels driven by a particular telos, such that the rise and resilience of neoliberalism seems almost inevitable - the neoliberal 'imaginary' working its magic without much obvious connection to the contestations, failures, and messy materiality of human life. But how exactly did the neoliberal imaginary that Konings describes so eloquently gain this much traction? Was its speculative temporality smoothly translated into practice from the writings of Hayek and others (as Konings seems to suggest), or was its production a messier, more contested, and more contingent affair? In this brief commentary, I will go back to one of the key historical

\section{Corresponding author:}

Jacqueline Best, School of Political Studies, University of Ottawa, 120 University Private, Ottawa, Ontario K1N 6N5, Canada. Email: jbest@ottawa.ca 
moments that he examines, the Volcker shock of 1979-82, and examine some of the more mundane political and technical struggles that defined the early Reagan Administration's efforts to put the neoliberal speculative logic into practice.

In revisiting this moment in time, I will be taking a path that Konings flags at various points in the book itself without ever quite following, but which I believe would ultimately both substantiate and complicate some of the most important insights of his book. That path involves a more thorough engagement with the materiality of the speculative logic of neoliberal finance, drawing on some of the theoretical approaches that Konings identifies in the book new materialism, the social studies of finance, cultural economy and, above all, actor network theory (at least in its earlier incarnations). A more substantial engagement with the insights from these theories would help to move Konings' analysis further towards the kind of immanent ontology he gestures towards in the book, and which is at the heart of many (if not all) of the philosophers that he engages, allowing us to understand the material work that is needed to produce and reproduce the speculative temporality of neoliberalism.

In reading Konings' treatment of money as leverage, I was immediately struck by its parallels with actor network theory's concepts of enrollment and inscription. In their earlier work, Bruno Latour and Steve Woolgar (1979) sought to make sense of the scientific process. Rather like the character of money in Konings' analysis, they found the value and security of certain scientific findings weren't simply given, but had to be actively produced - not only through the marshalling and manipulation of objects in the lab, but also through the translation of initial findings into various inscriptions (such as scientific papers, standards, metrics, devices, and so on). Yet, for these inscriptions to have value - like money - they needed to circulate, to be known, to be perceived as facts, and to be acted on as if they were facts. Thus, the complex social networks that make up academia and its relations with government, business, and the wider population remain vital to the production and validation of any scientific fact. Bringing Konings' insights to bear in this other domain, one could thus argue that scientific research, like credit-making, is characterized by a speculative temporality that relies on a kind of pre-emptive leverage for its ongoing validation.

Yet, we might also want to bring some of the insights from this earlier incarnation of actor network theory to bear on Konings' analysis as well. For what we discover when we read early actor network theory analyses of scientific practice is just how thickly material and social these valuation processes are. In the lab, the scientist makes use of a range of devices and objects that are themselves at least in part social products - metrics, procedures, and even animals like the genetically engineered fruit flies and mice whose standardization is so crucial to the production of stable and reproducible scientific findings. Moreover, if the scientist's laboratorybased findings are to become facts in the 'outside' world (a distinction that ultimately breaks down), the scientist must also try to remake and stabilize that world into something that partly resembles the lab for her findings to be successfully translated there. Latour's book on Pasteur, for example, describes how the scientist sought to extend his initial experiments on vaccination into the field, requiring farmers to disinfect, record, and otherwise help to reproduce the laboratory's conditions (Latour, 1993: 151-52).

Crucially, all of these processes are fragile, contingent, and prone to failure. So much can and does go wrong - not just in how the humans involved behave, but also in the objects themselves, which don't always do what they are supposed to do - like the scallops who refuse to anchor, and thus be enrolled, in Callon's (1986) discussion of the political economy of St. Brieu Bay. Yet scientific facts continue to be produced through hybrid processes that are both highly technical and immensely political, extremely powerful but also always fragile. 
Although lab mice and scallops might seem a very long ways indeed from the world of finance, it is not hard to see why many scholars operating with the field of science and technology studies have found the study of economic theory and practice to be so interesting. And while Konings (2018: 40-43) is right to challenge some of these theorists' more recent work on finance for sometimes vacillating between naïve realism and idealism, there are still some very useful ideas contained in these earlier analyses of the ways in which scientific facts come to be produced and valorized.

Was neoliberalism's pre-emptive temporal logic translated transparently into institutional life, or did it require the production of new metrics and technologies? I think that if we borrow some of the insights from more immanent perspectives, we may find we can trace and track its emergence and contestation over a host of meso-level practices that worked to anchor the new meanings of the emergent neoliberal order and validate their claims to facticity. The example of the invention of double-entry bookkeeping that Konings (2018: 73-4) introduces at one point is instructive here. Konings convincingly argues that part of the significance of this accounting innovation was the way in which the new ledgers made the uncertainty of financial futures not only visible but also actionable. These very concrete new accounting practices played a central part in the development of the speculative temporality of finance. ${ }^{1}$

In fact, there are a good number of such key moments in which changes to the metrics and instruments of financial management helped to nudge practices either towards (or sometimes away from) the speculative world in which we now live. While Donald Mackenzie and others have identified a number of more recent moments (MacKenzie, 2007; Millo and Mackenzie, 2009), I would like to turn to one that Konings identifies as a turning point of sorts in his book: the Volcker shock of 1979-82. The Federal Reserve Board's decision, in October of 1979, to explicitly adopt a monetarist strategy and begin reducing the expansion of the money supply was undoubtedly a crucial step in the emergence of the contemporary neoliberal financial system. Konings goes as far as to suggest that it was Paul Volcker's move that ultimately led to the expansion of the shadow banking system, and thus the return of free, speculative finance (Konings, 2018: 28, 110). He acknowledges that the monetarist experiment itself was ultimately deemed a failure, but argues that it was Volcker's willingness to gamble on a dramatic rupture with the past, and to court a productive kind of failure, that made this such a formative moment in neoliberalism's rise.

There is no doubt that Volcker, like many other conservative political and economic figures of the time, was hoping that the Fed's dramatic announcement of its shift to monetarism would help to shock the public into scaling back its inflationary expectations. There is also little doubt that, as Konings so powerfully argues here and in his earlier book, the appeal of neoliberal economic theories at this difficult political time was as much emotional and moral as it was technical (see Konings, 2015). And yet, if we look a little more closely at the unglamorous techniques and metrics that were required to make this shift possible, we find a much more material, contingent, and politically contested set of practices at work. It turns out that it wasn't very easy to take the speculative logic contained in monetarism, Hayekian theory, and new classical theory and make it visible and actionable in a way that was politically viable.

I have argued elsewhere that the most interesting and significant failures are the contested failures - those that lead to a fundamental debate about the metrics that define success itself (Best, 2014). The failure of monetarism - and, equally importantly, of supplyside economics - was profoundly contested. Even among neoliberal 'true believers', like the economists on the President's Economic Advisory Board (who included Milton Friedman and Alan Greenspan), there was enormous debate about what was going wrong and why. ${ }^{2}$ This 
debate became particularly acute in 1982, as the recession that President Reagan's advisors had promised would be mild, proved to be anything but, and as the effects of Reagan's tax cuts and defense spending, combined with the automatic stabilizers that kicked in during the recession, started to produce projections of extremely high future deficits - forcing a dramatic set of revisions to the initially very optimistic projections presented in February 1981 when Reagan introduced his economic plan.

Drawing inspiration from Koning's insights into the speculative character of financial governance, we can see how crucial these projections of a particular kind of economic future in fact were. The validation of the Reagan Administration's promises to tackle inflation depended on the public's acceptance of its possibility and their translation of this acceptance into lower inflationary expectations (which in concrete terms, meant lower wage demands from unionized workers and lower interest rates charged by banks). The gamble that they were making was that through a series of shocks to the system - not only the sudden reduction in the supply of money, but also the supply-side driven changes to tax rates and economic regulations - they could turn the vicious cycle of inflationary expectations and stagnation into a virtuous circle. Optimistic projections would play a crucial role in this highly speculative move, validating these economic claims, which in turn would foster the very confidence that would make them true.

In practice, it turned out, rhetoric was not enough and the metrics were unable to do the performative work they had been assigned. As the Undersecretary for Monetary Affairs, Beryl Sprinkel (a former student of Milton Friedman) noted in an apologetic memo to the Treasury Secretary, Donald Regan, the original projections, which proved to be so faulty, were in fact a compromise among economic advisors who couldn't agree on just how radical the rational expectations and supply-side assumptions should be. ${ }^{3}$ Greenspan and Murray Weidenbaum, Chair of Reagan's Council of Economic Advisers, were particularly concerned that projections that assumed too rapid a decrease in inflation would not be believed, undermining the credibility of the Administration's position. So those responsible for the first Reagan budget fudged the numbers, assuming a massive increase in monetary velocity to make the growth numbers come out the way that they wanted them to. Yet those inconsistent numbers themselves turned out to be far from credible to the financial community, and the Reagan Administration's efforts to force a shift towards a more speculative economic logic was undermined by the very metrics they had hoped would support their gamble.

Part of what is so fascinating in unpacking these internal debates (and I am barely scratching the surface in this brief account), is how they show the friction involved in translating theory into practice. Monetarist theory argued that the Federal Reserve Board was able to control the money supply, and yet the Fed's efforts to do so were a disaster, provoking unprecedented volatility in interest rates. Monetarist and supply-side theories also insisted that deficits didn't matter for inflation, as long as they weren't monetized (i.e., supported by the central bank printing money) - and yet deficits clearly did matter as long as the public and banks believed they did and continued to expect higher inflation as the consequence. Rational expectations theory predicted that consumers' and financial actors' inflationary expectations would adjust in real-time to the Fed's declaration of a much lower money supply target - and yet they didn't, as members of Reagan's Administration were forced to admit there was an important lag in expectations, which would translate into a much more painful transition to a low inflation world. ${ }^{4}$

How did they respond to these setbacks? Although Sprinkel, Regan, and others did admit (at least among themselves) that their assumptions about expectations and the deficit did not hold true, on the question of whether monetarism was a failure, they engaged in denial: 
Sprinkel, Regan, and Friedman argued that this wasn't a real monetarist experiment, because Volcker and the Fed weren't adhering closely enough to monetarist principles. ${ }^{5}$ As it turned out, this was a misdiagnosis, and the main source of the problem was the simple fact that the deregulation of finance that the Reagan government undertook at the same time had dramatically changed people's use of money, altering its velocity and making it extremely difficult to control. ${ }^{6}$

This was not a failure caused by a disconnection between the neoliberal fiction and hard economic reality, as heterodox and critical political economists might argue. Nor was it a constructive failure engineered by Volcker and others to disrupt and change the game along neoliberal lines, as Konings suggests. It was instead what I have described elsewhere as a failure of performativity (Best, 2014: 192), in which the provisional and performative logic of the policy did not succeed on its own terms. In Koning's language, it was a failure of the Reagan Administration's speculative move - its attempt to use its leverage to lean forward, gain commitment and connections with others, and engineer a one-way bet in which the uncertain future would validate its present claims.

How, then, did the neoliberal agenda ultimately succeed and land us where we are today? Although Volcker and Reagan's advisors talked a good line about the need to shock the American economy out of an inflationary spiral through a dramatic move that would shift expectations overnight, in the end, much of the hard work of lowering inflation was done through old-fashioned demand-side deflation. ${ }^{7}$ The neoliberal imaginary and the speculative, self-fulfilling logic that it entailed, could not work outside the virtual lab of economic theory until the world had been at least partly reshaped in its image. This was a very messy moment indeed as the valorization of the new neoliberal imaginary required relying on some very oldschool practices, even as policymakers were struggling to invent a new set of techniques that would enable the new speculative projections to work. Expectations turned out not to be fully rational or capable of adjusting instantly to changed policies, but instead were sticky, pragmatic, and linked to everyday habits inculcated over time. The way these expectations were translated into practice was also dependent on various non-financial nodes of power, like that of the unions, who were one of the main casualties of the brutal American and British recessions, and whose decline made it far easier for neoliberal logics of leverage to operate smoothly. ${ }^{8}$

Yet how smooth is the neoliberal logic of leverage, even today? Although neoliberalism seems only to have gained in self-referential power in the aftermath of the 2008 financial crisis, if we bring a greater awareness of the contingency and materiality of its day-to-day reproduction to bear on our analysis, we can begin to see it as less than monolithic. As I have argued elsewhere (Best, 2019), we should be wary of being seduced by central bankers' and economists claims that inflation-targeting is still working - or in fact has ever worked as promised - when looking under the hood reveals a more contingent and fragile set of metrics and mechanics. This is not to return to a kind of Polanyian romanticism about the inherently artificial nature of financial disembedding and the inevitability of a countervailing move to reembed economy in society. It is instead to engage in an immanent critique by paying attention to the messy practicalities of the neoliberal bet.

As Konings so powerfully argues, successful leverage requires a continuous process of enrolment and networking, of making real and factual present claims by projecting forwards to a secure and self-confirming future. There is enormous work involved in producing a world that confirms to neoliberal economic theory, or at least diverges in ways that can be effectively ignored. Although governing through risk means always seeking to pre-empt the next failure, we still need to ask ourselves whether this transformation is ever really successful. If not, 
perhaps it is possible to imagine a future in which a series of neoliberal failures - some of them quite mundane - would allow us to escape the teleological trap that Konings seems to leave us with; not through a sudden rupture or a romantic re-embedding, but rather through a slow and uncertain stumble towards a less painfully unfair political and economic world.

\section{Notes}

1. For a discussion of the emergence and spread of early accounting techniques that draws on actor network theory, see Quattrone (2009).

2. Library of Congress Manuscript Division, Donald T. Regan Collection. Box 162, Subject files. President's Economic Advisory Board, 1981 \& 1982. Various files.

3. Library of Congress Manuscript Division, Donald T. Regan Collection. Box 56, File 4. Memorandum to Regan from Beryl Sprinkel, Subject: Why our initial forecast went wrong. November 3, 1982.

4. US National Archives II, RG56-UD-11W34. Subject files: Under-Secretary for Monetary Affairs. Box 1, File 3: 1982 CCEA \& Related. Talking points for Beryl Sprinkel, Cabinet Council on Economic Affairs meeting. August 10, 1982.

5. This is remarkably similar to a discussion by Latour of an experiment that depended on a guinea pig gut to produce its findings, but which turned out to be less reliable than initially hoped: "Just at the time when we feel comforted in our belief and start to be fully convinced by our own eyes watching the image, we suddenly feel uneasy because of the fragility of the whole set up. The Professor, for instance, is swearing at the gut saying it is a 'bad gut'. The technician who sacrificed the guinea pig is held responsible and the Professor decides to make a fresh start with a new animal ... Suddenly, we are much further from the paper world of the article. We are now in a puddle of blood and viscera, slightly nauseated by the extraction of the ileum from this little furry creature" (Latour, 1987: 66).

6. The veritable war that Sprinkel in particular waged on Volcker, together with Volcker's very public criticisms of the deficits implied by Reagan's supply-side tax-cutting agenda, also points to the huge internal conflicts over economic policy, suggesting we should not too easily read Volcker's actions as the state's necessary response to excessive financial entanglement (Konings, 2018: 100, 109-10).

7. This dynamic is even clearer in the United Kingdom, where Thatcher backed away from raising interest rates quite quickly and used budget cuts and unemployment to squeeze inflation out of the economy (see Best, 2019).

8. The success of the Reagan and Thatcher governments also owed a great deal to their hawkish stances on national security, another source of affective appeal that combined in complicated ways with the emotional logic of neoliberalism that Konings (2015) explores in his earlier book.

\section{References}

Best, J. (2014) Governing Failure: Provisional Expertise and the Transformation of Global Development Finance. Cambridge: Cambridge University Press.

Best, J. (2019) The inflation game: Targets, practices and the social production of monetary credibility. New Political Economy, doi.org/10.1080/13563467.2018.1484714

Callon, M. (1986) Some elements of a sociology of translation: Domestication of the scallops and the fishermen of St. Brieuc Bay. In: J. Law (ed.), Power, Action, and Belief: A New Sociology of Knowledge? London: Routledge \& Kegan Paul, 196-233. 
Konings, M. (2015) The Emotional Logic of Capitalism: What Progressives Have Missed. Stanford, CA: Stanford University Press.

Konings, M. (2018) Capital and Time: For a New Critique of Neoliberal Reason. Stanford, CA: Stanford University Press.

Latour, B. (1987) Science in Action. Milton Keynes: Open University.

Latour, B. (1993) The Pasteurization of France, translated by A. Sheridan and J. Law. Cambridge, MA: Harvard University Press.

Latour, B. and Woolgar, S. (1979) Laboratory Life: The Construction of Scientific Facts. Beverly Hills, CA: Sage.

MacKenzie, D. (2007) The material production of virtuality: Innovation, cultural geography and facticity in derivatives markets. Economy and Society, 36(3): 355-76.

Millo, Y. and MacKenzie, D. (2009) The usefulness of inaccurate models: Towards an understanding of the emergence of financial risk management. Accounting, Organizations and Society, 34(5): 63853.

Quattrone, P. (2009) Books to be practiced: Memory, the power of the visual, and the success of accounting. Accounting, Organizations and Society, 34(1): 85-118. 